\title{
Optimasi Produksi Buis Beton Menggunakan Model De Novo Programming Pada PT.X
}

\author{
Resqy Sellva Budianti* \\ Prodi Matematika, Fakultas Matematika dan Ilmu Pengetahuan Alam, Universitas \\ Islam Bandung, Indonesia. \\ *resqysellva@gmail.com
}

\begin{abstract}
PT.X is an industry that provides various types of construction materials, one of which is the manufacture of concrete buis. There are seven types of buis concrete produced. The raw materials used in the manufacture of buis concrete are sand, cement and water. When producing concrete buis, sometimes there is an excess or residual raw material, which caused by the inaccurate calculation of the raw material requirements. The aim of this paper is to optimize the production of concrete buis according to the available resources so that there are no residues. De Novo programming model is used and then formulated into a linear programming model using the simplex method. The calculation results the optimum numbers of production are 216 buis concrete type 20, 238 buis concrete type 30,142 buis concrete type 40,130 buis concrete type 50,112 buis concrete type 60,125 buis concrete type 80 , and 150 buis concrete type 100 with total production profit in March 2021 of Rp. 47,685,060.58.
\end{abstract}

Keywords: : Production Optimization, Concrete Buis, De novo Programming, Simplex Method

\begin{abstract}
Abstrak. PT.X merupakan industri penyedia berbagai jenis material konstruksi salah satunya pembuatan buis beton. Terdapat tujuh jenis tipe buis beton yang diproduksi. Bahan baku yang digunakan dalam pembuatan buis beton yaitu pasir, semen dan air. Saat memproduksi buis beton terkadang terjadi kelebihan atau sisa bahan baku yang penyebabnya diperkirakan pada kurang tepatnya memperhitungkan kebutuhan bahan baku, sedangkan dalam pembuatan beton terdapat spesifikasi tertentu yang harus terpenuhi sehingga diupayakan agar tidak adanya sisa bahan baku saat proses produksi. Diperlukan optimasi produksi buis beton sesuai dengan sumber daya yang tersedia agar tidak terdapat sisa, digunakan model de novo programming kemudian diformulasikan ke dalam model linear programming dengan metode simpleks. Hasil perhitungan diperoleh jumlah masing-masing produk buis beton diantaranya buis beton tipe 20 sebanyak 216 , buis beton tipe 30 sebanyak 238, buis beton tipe 40 sebanyak 142, buis beton tipe 50 sebanyak 130, buis beton tipe 60 sebanyak 112 , buis beton tipe 80 sebanyak 125 dan buis beton tipe 100 sebanyak 150 dengan total keuntungan produksi pada bulan Maret 2021 yaitu Rp. 47.685.060,58. Penggunaan model de novo programming dapat mengoptimalkan bahan baku yang tersedia sehingga diharapkan mampu memenuhi spesifikasi produk buis beton yang telah ditetapkan dan keuntungan yang diperoleh maksimum.
\end{abstract}

Kata Kunci: Optimasi Produksi, Buis Beton, De novo Programming, Metode Simpleks 


\section{A. Pendahuluan}

Sejak satu tahun terakhir tepatnya dari tahun 2020 sampai saat ini, telah terjadi pandemi Corona Virus Disease 2019 (COVID-19) yang sudah menyebar dan menginfeksi ratusan ribu orang diberbagai belahan dunia, termasuk Indonesia. Guna mencegah dan menangani penyebaran COVID-19 pemerintah Indonesia membuat suatu kebijakan seperti diberlakukannya work from home (WFH), Pembatasan Sosial Berskala Besar (PSBB), menunda kegiatan yang mengumpulkan banyak orang dan kebijakan lainnya [1]. Hal tersebut menyebabkan terganggunya hampir di seluruh kegiatan masyarakat, termasuk kegiatan yang berkaitan dengan bisnis atau usaha [2], seperti perusahaan PT.X karena pandemi COVID-19 pengiriman dan penerimaan bahan baku yang dibutuhkan dalam proses produksi menjadi terhambat. Dalam menghadapi dampak dari pandemi tersebut dibutuhkan suatu strategi oleh setiap usaha atau pengelola bisnis agar usahanya tetap bertahan dalam situasi pandemi, salah satunya dengan membuat perencanaan produksi yang tepat. Perencanaan produksi merupakan salah satu fungsi manajemen terkait pengambilan keputusan yang akan ditentukan oleh pimpinan perusahaan untuk mencapai tujuan perusahaan [3]. Banyak kondisi yang harus diperhatikan dalam proses perencanaan produksi, salah satunya adalah sumber daya. Perusahaan akan dituntut untuk memanfaatkan sumber daya yang tersedia secara optimal agar perusahaan mendapatkan keuntungan yang maksimal [4]. Biasanya setiap perusahaan akan membuat perencanaan produksi terkait optimasi produksi sesuai dengan sumber daya yang tersedia. Optimasi produksi yaitu suatu cara untuk merencanakan atau mengatur penggunaan sumber daya yang tersedia [5].

PT.X merupakan perusahaan yang bergerak di bidang industri penyedia berbagai jenis material kontruksi salah satunya pembuatan buis beton atau gorong-gorong. Buis beton atau gorong-gorong beton merupakan salah satu bahan material kontruksi atau bahan bangunan yang pada dasarnya berfungsi sebagai pelapis dinding tanah dalam pembuatan sumur resapan, saluran air dimana sering digunakan oleh sejumlah perumahan atau di tempat umum [6]. Terdapat tujuh jenis tipe buis beton yang diproduksi yaitu tipe 20 , tipe 30 , tipe 40 , tipe 50 , tipe 60 , tipe 80 dan tipe 100. Bahan baku yang digunakan dalam pembuatan buis beton yaitu pasir, semen dan air. Saat memproduksi buis beton terkadang terjadi kelebihan atau sisa bahan baku seperti pasir atau air, yang penyebabnya diperkirakan pada perencanaan produksi yang tidak tepat terkait memperhitungkan kebutuhan bahan baku. Dalam pembuatan beton terdapat spesifkasi tertentu yang harus dipenuhi, dengan tidak terdapatnya sisa bahan baku saat proses produksi diharapkan dapat memenuhi spesifikasi beton yang telah ditetapkan. Untuk mengoptimalkan jumlah produksi buis beton sesuai dengan bahan baku yang tersedia agar tidak terdapat sisa, digunakan model de novo programming dengan penyelesaian perhitungan menggunakan metode simpleks. Penyelesaian masalah optimasi menggunakan model de novo programming dilakukan dengan pendekatan sistem secara total artinya selain menentukan kombinasi terbaik terhadap hasilnya juga memberikan suatu usulan penggunaan sumber daya yang terintegrasi melalui anggaran yang tersedia [7].

Penelitian terkait dapat ditemukan pada studi oleh Iriani mengenai efektivitas perencanaan produksi beton dengan pendekatan de novo programming [7] dan studi oleh Enny Ariyani mengenai perencanaan produksi keramik tile dengan metode de novo programming untuk memperoleh keuntungan yang maksimal di PT. Keramik Diamond Industries Gresik [8].

\section{B. Metodologi}

\section{Optimasi}

Dalam matematika optimasi merupakan salah satu disiplin ilmu yang fokus untuk mendapatkan nilai maksimum atau minimum secara sistematis dari suatu fungsi, peluang, ataupun pencarian nilai lainnya yang digunakan dalam berbagai kasus [9]. Optimasi dalam dunia usaha atau bisnis termasuk ke dalam kegiatan perencanaan produksi. Optimasi produksi yatu suatu cara untuk merencanakan atau mengatur penggunaan sumber daya yang tersedia seperti modal kerja, bahan baku, tenaga kerja, fasilitas produksi agar dapat memenuhi permintaan produksi. Setiap perusahaan akan berusaha mencapai keadaan optimal dalam optimasi produksi untuk mencapai hasil keuntungan yang maksimum. Banyak cara untuk mengoptimalkan produksi seperti meningkatkan kualitas produksi, kegunaan produksi, mengembangkan bentuk fisik dari produk 
dan mengatur jumlah produksi [10].

\section{Linear Programming}

Pemrograman linier (linear programming) merupakan salah satu teknik pengambilan keputusan dalam memecahkan permasalahan pengalokasian sumber daya yang terbatas se-optimal mungkin [11]. Secara umum pemrograman linier merupakan salah satu penyelesaian riset operasi, utamanya dalam permasalahan optimasi yaitu memaksimumkan atau meminimukan [12]. Penyelesaian masalah menggunakan pemrograman linier yang terbukti dapat menyelesaikan persoalan optimasi dan digunakan pada situational problem, di antaranya mengenai penggunaan program linier dalam memaksimalkan keuntungan [13]. Karakteristikkarakteristik yang digunakan dalam persoalan linear programming diantaranya variabel keputusan, fungsi tujuan (objective function) dan batasan atau kendala (constraint) [14].

Model linear programming digunakan untuk persoalan optimasi (memaksimumkan atau meminimumkan) yang terdiri atas satu fungsi tujuan dan sejumlah $\mathrm{m}$ sumber yang terbatas untuk dialokasikan pada sejumlah $\mathrm{n}$ tingkat kegiatan adalah sebagai berikut [15]:

Fungsi Tujuan:

Kendala:

$$
Z=C_{1} X_{1}+C_{2} X_{2}+\cdots+C_{n} X_{n}
$$

Kendala Fungsional:

$$
\begin{gathered}
a_{11} X_{1}+a_{12} X_{2}+\cdots+a_{1 n} X_{n}(\leq,=, \geq) b_{1} \\
a_{21} X_{1}+a_{22} X_{2}+\cdots+a_{2 n} X_{n}(\leq,=, \geq) b_{2} \\
\vdots \\
a_{m 1} X_{1}+a_{m 2} X_{2}+\cdots+a_{m n} X_{n}(\leq,=, \geq) b_{m}
\end{gathered}
$$

Kendala Non-Negatif:

$$
X_{1}, X_{2}, \cdots, X_{n} \geq 0
$$

\section{De Novo Programming}

Zenely mengemukakan suatu cara untuk melihat sistem yang selain mengoptimalkan sistem yang sudah ada, juga merancang suatu sistem yang optimal dan dititikberatkan pada membuat suatu desain yang optimal terhadap sistem dengan produktivitas (kemampuan untuk mengahasilkan sesuatu) tinggi yang mempunyai banyak kriteria (Multiple Criteria) [16].

Perbedaan antara pendekatan mengoptimalkan suatu sistem dengan pendekatan mendesain sistem yang optimal antara lain sebagai berikut.

1. Pendekatan linear programming yaitu pendekatan mengoptimalkan suatu sistem dimana pada setiap batasan sumber daya dianggap sudah ditetapkan sebelumnya dan jika terjadi penggunaan sumber daya yang tidak sepenuhnya (terdapat sisa) maka dianggap tidak mempengaruhi produktivitas sistem [17].

2. Pendekatan de novo programming yaitu pendekatan mendesain sistem yang optimal dimana kendala sumber daya akan disusun sehingga tidak menghasilkan sisa.

Pendekatan de novo programming dalam menyelesaikan masalah optimasi dilakukan dengan pendekatan sistem secara total artinya selain menentukan kombinasi terbaik yang optimal terhadap hasilnya dan dapat memberikan suatu usulan penggunaan sumber daya yang terintegrasi (penggabungan) melalui anggaran yang tersedia karena adanya keterbatasan anggaran yang merupakan syarat penting dalam formulasi de novo programming [7].

Formulasi pendekatan de novo programming (DNP) untuk persoalan optimasi (memaksimumkan) yang terdiri atas satu fungsi tujuan dan sejumlah $m$ sumber yang terbatas untuk dialokasikan pada sejumlah $\mathrm{n}$ tingkat kegiatan serta anggaran (budget) yang tersedia adalah sebagai berikut [7]: 
Fungsi Tujuan:

Kendala:

$$
Z=C_{1} X_{1}+C_{2} X_{2}+\cdots+C_{n} X_{n}
$$

$$
\begin{gathered}
v_{1} X_{1}+v_{2} X_{2}+\cdots+v_{n} X_{n} \leq B \\
a_{21} X_{1}+a_{22} X_{2}+\cdots+a_{2 n} X_{n} \leq b_{2} \\
X_{1}, X_{2}, \cdots, X_{n} \geq 0
\end{gathered}
$$

Model de novo programming yang terdiri atas satu fungsi tujuan dan terdapat kendala selain bahan baku serta anggaran seperti kapasitas produksi, permintaan produksi atau kendala lainnya yang dianggap baku bagi perusahaan, maka model de novo programming dapat dimodelkan dalam bentuk linear programming. Metode penyelesaian linear programming yang digunakan adalah metode grafik untuk kasus dua variabel keputusan dan untuk kasus lebih dari dua variabel keputusan salah satunya dengan metode simpleks. Model de novo programming tidak dapat digunakan dalam penyelesaian permasalahan dengan fungsi tujuan berupa minimasi biaya produksi, karena salah satu kendala dari model de novo programming yaitu kendala keterbatasan anggaran (budget) [7].

\section{Penyelesaian Linear Proramming Menggunakan Metode Simpleks}

Metode simpleks merupakan salah satu teknik penyelesaian dalam linear programming yang digunakan sebagai teknik pengambilan keputusan dalam mencari nilai optimal yang melibatkan banyak pertidaksamaan dan multivariabel [18]. Kelebihan dari metode simpleks mampu menyelesaikan kasus dua atau lebih variabel keputusan [19]. Berikut langkah-langkah perhitungan metode simpleks secara analitik antara lain [20]:

1. Mengubah fungsi tujuan dan batasan atau kendala.

2. Menyusun persamaan-persamaan ke dalam tabel simpleks, bentuk tabel awal simpleks dengan kendala berbentuk pertidaksamaan lebih kecil dari atau sama dengan $(\leq)$ yaitu sebagai berikut.

Tabel 2.1. Tabel awal simpleks

\begin{tabular}{|c|c|c|c|c|c|c|c|c|c|c|}
\hline Variabel Basis & $\mathrm{Z}$ & $\mathrm{X}_{1}$ & $\mathrm{X}_{2}$ & $\cdots$ & $\mathrm{X}_{\mathrm{n}}$ & $\mathrm{S}_{1}$ & $\mathrm{~S}_{2}$ & $\cdots$ & $\mathrm{S}_{\mathrm{n}}$ & Solusi \\
\hline $\mathrm{Z}$ & 1 & $-\mathrm{C}_{1}$ & $-\mathrm{C}_{2}$ & $\cdots$ & $-\mathrm{C}_{\mathrm{n}}$ & 0 & 0 & $\cdots$ & 0 & 0 \\
\hline $\mathrm{S}_{1}$ & 0 & $\mathrm{a}_{11}$ & $\mathrm{a}_{12}$ & $\cdots$ & $\mathrm{a}_{1 \mathrm{n}}$ & 1 & 0 & $\cdots$ & 0 & $\mathrm{~b}_{1}$ \\
\hline $\mathrm{S}_{2}$ & 0 & $\mathrm{a}_{21}$ & $\mathrm{a}_{22}$ & $\cdots$ & $\mathrm{a}_{2 \mathrm{n}}$ & 0 & 1 & $\cdots$ & 0 & $\mathrm{~b}_{2}$ \\
\hline$\vdots$ & $\vdots$ & $\vdots$ & $\vdots$ & $\vdots$ & $\vdots$ & $\vdots$ & $\vdots$ & $\vdots$ & $\vdots$ & $\vdots$ \\
\hline $\mathrm{S}_{\mathrm{n}}$ & 0 & $\mathrm{a}_{\mathrm{m} 1}$ & $\mathrm{a}_{\mathrm{m} 2}$ & $\cdots$ & $\mathrm{a}_{\mathrm{mn}}$ & 0 & 0 & $\cdots$ & 1 & $\mathrm{~b}_{\mathrm{m}}$ \\
\hline
\end{tabular}

3. Menentukan kolom kunci.

4. Menentukan baris kunci.

5. Mengubah nilai-nilai baris kunci.

6. Mengubah nilai-nilai diluar baris kunci.

7. Perlu dipastikan agar tabel sudah optimal, keadaan optimal dilihat berdasarkan koefisien fungsi tujuan (nilai yang terdapat pada baris z) dan tergantung dari bentuk tujuan.

\section{Pembahasan dan Diskusi}

Data pembuatan buis beton pada bulan Maret 2021 yang digunakan dalam penyelesaian masalah optimasi produksi terkait penentuan jumlah produksi buis beton sesuai dengan sumber daya yang tersedia agar tidak terdapat sisa, menggunakan model de novo programming dengan penyelesaian perhitungan metode simpleks antara lain: jenis-jenis produk, komposisi bahan baku, ketersediaan bahan baku, harga bahan baku, kapasitas produksi, permintaan produksi dan keuntungan produk. 


\section{Langkah 1: Menentukan variabel keputusan.}

Variabel keputusan yang digunakan untuk penentuan setiap produk buis beton yang akan diproduksi setiap bulan sebagai berikut.

$\mathrm{X}_{1}$ : Jumlah buis beton tipe 20

$\mathrm{X}_{2}$ : jumlah buis beton tipe 30

$\mathrm{X}_{3}$ : Jumlah buis beton tipe 40

$\mathrm{X}_{4}$ : Jumlah buis beton tipe 50

$\mathrm{X}_{5}$ : Jumlah buis beton tipe 60

$\mathrm{X}_{6}$ : Jumlah buis beton tipe 80

$\mathrm{X}_{7}$ : Jumlah buis beton tipe 100

Langkah 2: Menentukan fungsi tujuan.

Dalam mengoptimalkan produksi buis beton yang digunakan sebagai fungsi tujuan yaitu keuntungan setiap produk. Berdasarkan keuntungan produk dapat diformulasikan untuk keuntungan total yang dihasilkan setiap bulan oleh PT.X yaitu:

Maksimasi: $Z=30.400 \mathrm{X}_{1}+35.462,40 \mathrm{X}_{2}+39.640 \mathrm{X}_{3}+45.800 \mathrm{X}_{4}+48.500 \mathrm{X}_{5}+$ $54.280 \mathrm{X}_{6}+59.191,40 \mathrm{X}_{7}$

\section{Langkah 3: Menentukan kendala-kendala.}

Kendala-kendala yang mempengaruhi dalam proses produksi yang digunakan sebagai fungsi kendala dalam perhitungan antara lain:

1. Kendala sumber daya

Dalam memproduksi berbagai jenis produk buis beton di PT.X digunakan tiga macam bahan baku terlihat pada Tabel 3.1.

Tabel 3.1. Komposisi Bahan Baku

\begin{tabular}{|c|c|c|c|c|c|c|c|c|c|}
\hline \multirow[b]{2}{*}{$\begin{array}{l}\mathrm{N} \\
\mathrm{O}\end{array}$} & \multirow{2}{*}{$\begin{array}{c}\text { Jenis } \\
\text { Bahan } \\
\text { Baku }\end{array}$} & \multicolumn{7}{|c|}{ Jenis Produk } & \multirow{2}{*}{$\begin{array}{l}\text { Sat } \\
\text { uan }\end{array}$} \\
\hline & & $\begin{array}{c}\text { Buis } \\
\text { Beton } \\
20 \\
\end{array}$ & $\begin{array}{c}\text { Buis } \\
\text { Beton } \\
30 \\
\end{array}$ & $\begin{array}{c}\text { Buis } \\
\text { Beton } \\
40 \\
\end{array}$ & $\begin{array}{c}\text { Buis } \\
\text { Beton } \\
50 \\
\end{array}$ & $\begin{array}{c}\text { Buis } \\
\text { Beton } \\
60 \\
\end{array}$ & $\begin{array}{c}\text { Buis } \\
\text { Beton } \\
80 \\
\end{array}$ & $\begin{array}{c}\text { Buis } \\
\text { Beton } \\
100 \\
\end{array}$ & \\
\hline 1 & Pasir & 35 & 40 & 56 & 70 & 87.5 & 112 & 127.27 & $\mathrm{Kg}$ \\
\hline 2 & Semen & 15 & 17.14 & 24 & 30 & 37.5 & 48 & 54.54 & $\mathrm{Kg}$ \\
\hline 3 & Air & 5 & 5.68 & 8 & 10 & 12.5 & 16 & 18.18 & $\mathrm{Kg}$ \\
\hline
\end{tabular}

Bahan baku merupakan salah satu faktor yang berperan penting dalam proses produksi [21]. Bahan baku yang tersedia dalam memproduksi buis beton pada bulan Maret 2021 terlihat pada tabel 3.2.

Tabel 3.2. Ketersediaan Bahan Baku

\begin{tabular}{|c|c|c|}
\hline Jenis Bahan Baku & Ketersediaan & Satuan \\
\hline Pasir & 77000 & $\mathrm{Kg}$ \\
\hline Semen & 33000 & $\mathrm{Kg}$ \\
\hline Air & 12000 & $\mathrm{Kg}$ \\
\hline
\end{tabular}

Berdasarkan data komposisi bahan baku dan ketersediaan bahan baku diatas, maka kendala sumber daya dapat diformulasikan sebagai berikut:

$$
\begin{aligned}
& 35 X_{1}+40 X_{2}+56 X_{3}+70 X_{4}+87.5 X_{5}+112 X_{6}+127.27 X_{7}=77.000 \\
& 15 X_{1}+17.14 X_{2}+24 X_{3}+30 X_{4}+37.5 X_{5}+48 X_{6}+54.4 X_{7}=33.000 \\
& 5 X_{1}+5.68 X_{2}+8 X_{3}+10 X_{4}+12.5 X_{5}+16 X_{6}+18.18 X_{7}=12.000
\end{aligned}
$$


2. Kendala biaya (budget)

Data yang digunakan untuk formulasi kendala biaya (budget) yaitu harga bahan baku. Harga setiap bahan baku selama proses produksi pada bulan Maret 2021 terlihat pada Tabel 3.3.

Tabel 3.3. Harga Bahan Baku

\begin{tabular}{|c|c|}
\hline Jenis Bahan Baku & Satuan $(\mathrm{Rp} / \mathrm{Kg})$ \\
\hline Pasir & 300 \\
\hline Semen & 1.600 \\
\hline Air & 20 \\
\hline
\end{tabular}

Berikut tahapan-tahapan menentukan formulasi kendala biaya (budget).

1. Mencari total biaya (budget) dengan cara mengalikan harga masing-masing sumber daya dengan jumlah sumber daya yang tersedia kemudian dijumlahkan keseluruhan, maka total biaya yaitu:

2. Total biaya (B): $300(77.000)+1.600(33.000)+20(12.000)=76.140 .000$

3. Menghitung variabel cost $\left(\mathrm{v}_{\mathrm{j}}\right)$ yaitu biaya yang dibutuhkan untuk membuat setiap produk buis beton dengan menggunakan data pada Tabel 3.1 dan Tabel 3.3.

1) Buis beton tipe $20\left(\mathrm{v}_{1}\right)$ $\mathrm{v}_{1}=35(300)+15(1.600)+5(20)=34.600$

2) Buis beton tipe $30\left(\mathrm{v}_{2}\right)$ $\mathrm{v}_{2}=40(300)+17.14(1.600)+5.68(20)=39.537,60$

3) Buis beton tipe $40\left(\mathrm{v}_{3}\right)$ $\mathrm{v}_{3}=56(300)+24(1.600)+8(20)=55.360$

4) Buis beton tipe $50\left(\mathrm{v}_{4}\right)$ $\mathrm{v}_{4}=70(300)+30(1.600)+10(20)=69.200$

5) Buis beton tipe $60\left(\mathrm{v}_{5}\right)$ $\mathrm{v}_{5}=87.5(300)+37.5(1600)+12.5(20)=86.500$

6) Buis beton tipe $80\left(\mathrm{v}_{6}\right)$ $\mathrm{v}_{6}=112(300)+48(1.600)+16(20)=110.720$

7) Buis beton tipe $100\left(\mathrm{v}_{7}\right)$ $\mathrm{v}_{7}=127.27(300)+54.54(1.600)+18.18(20)=125.808,60$

3. Kendala kapasitas produksi

Kapasitas produksi di PT.X diambil berdasarkan kemampuan dari seluruh tenaga kerja dalam pembuatan buis beton yang sudah ditetapkan selama satu bulan terlihat pada Tabel 3.4. 
Tabel 3.4. Kapasitas produksi

\begin{tabular}{|c|c|c|c|}
\hline Jenis Produk & Kapasitas Produksi & Jumlah Pekerja & Alat Cetakan \\
\hline Buis Beton 20 & 250 & 1 & 1 \\
\hline Buis Beton 30 & 250 & 1 & 1 \\
\hline Buis Beton 40 & 200 & 1 & 1 \\
\hline Buis Beton 50 & 200 & 1 & 1 \\
\hline Buis Beton 60 & 150 & 2 & 2 \\
\hline Buis Beton 80 & 150 & 8 & 8 \\
\hline Buis Beton 100 & 250 & 1 & 1 \\
\hline Total & 1450 & 1 & 1 \\
\hline
\end{tabular}

Berdasarkan data kapasitas produksi per bulan maka formulasi kendala kapasitas produksi yaitu:

4. Kendala permintaan produk

$$
\mathrm{X}_{1}+\mathrm{X}_{2}+\mathrm{X}_{3}+\mathrm{X}_{4}+\mathrm{X}_{5}+\mathrm{X}_{6}+2 \mathrm{X}_{7} \leq 1450
$$

Data yang digunakan untuk formulasi kendala permintaan produk yaitu permintaan produk perbulan yaitu pada bulan Maret 2021. Berdasarkan data permintaan produk pada bulan Maret 2021 dan dengan berdasarkan pada pertidaksamaan $X_{j} \leq D_{j}$, yang dibentuk agar jumlah produksi tidak melebihi permintaan dimana $D_{j}$ merupakan besarnya permintaan terhadap jenis produk $\mathrm{j}(\mathrm{j}=1,2, \ldots, \mathrm{n})$ [7], sehingga kendala permintaan produk menjadi:

$$
\begin{aligned}
& X_{1} \leq 216 \\
& X_{2} \leq 238 \\
& X_{3} \leq 142 \\
& X_{4} \leq 130 \\
& X_{5} \leq 112 \\
& X_{6} \leq 125 \\
& X_{7} \leq 155
\end{aligned}
$$

Formulasi de novo programming dalam persoalan optimasi produksi buis beton sesuai dengan sumber daya yang tersedia menjadi:

Fungsi Tujuan:

$Z=30.400 X_{1}+35.462,40 X_{2}+39.640 X_{3}+45.800 X_{4}+48.500 X_{5}+54.280 X_{6}+$ $59.191,40 \mathrm{X}_{7}$

Kendala:

Kendala Biaya (budget):

$34.600 \mathrm{X}_{1}+39.537,60 \mathrm{X}_{2}+55.360 \mathrm{X}_{3}+69.200 \mathrm{X}_{4}+86.500 \mathrm{X}_{5}+110.720 \mathrm{X}_{6}+$ $125.808,60 \mathrm{X}_{7} \leq 76.140 .000$

Kendala Kapasitas Produksi:

$X_{1}+X_{2}+X_{3}+X_{4}+X_{5}+X_{6}+2 X_{7} \leq 1450$ 
Kendala Permintaan Produk:

$\mathrm{X}_{1} \leq 216$

$\mathrm{X}_{2} \leq 238$

$\mathrm{X}_{3} \leq 142$

$\mathrm{X}_{4} \leq 130$

$\mathrm{X}_{5} \leq 112$

$\mathrm{X}_{6} \leq 125$

$\mathrm{X}_{7} \leq 155$

Kendala non-negatif:

$\mathrm{X}_{1}, \mathrm{X}_{2}, \mathrm{X}_{3}, \mathrm{X}_{4}, \mathrm{X}_{5}, \mathrm{X}_{6}, \mathrm{X}_{7} \geq 0$

Setelah formulasi de novo programming yang diperoleh, kemudian diformulasikan ke dalam bentuk linear programming, yang selanjutnya penyelesaian perhitungan menggunakan metode simpleks. Berikut formulasi dalam bentuk standar simpleks dan langkah-langkah penyelesaian perhitungannya:

1. Mengubah fungsi tujuan dan kendala.

Fungsi tujuan:

$\mathrm{Z}-30.400 \mathrm{X}_{1}-35.462,40 \mathrm{X}_{2}-39.640 \mathrm{X}_{3}-45.800 \mathrm{X}_{4}-48.500 \mathrm{X}_{5}-54.280 \mathrm{X}_{6}-59.191,40 \mathrm{X}_{7}$ $=0$

Kendala:

$34.600 \mathrm{X}_{1}+39.537,60 \mathrm{X}_{2}+55.360 \mathrm{X}_{3}+69.200 \mathrm{X}_{4}+86.500 \mathrm{X}_{5}+110.720 \mathrm{X}_{6}+$ $125.808,60 \mathrm{X}_{7}+\mathrm{S}_{1}=76.140 .000$

$X_{1}+X_{2}+X_{3}+X_{4}+X_{5}+X_{6}+2 X_{7}+S_{2}=1450$

$\mathrm{X}_{1}+\mathrm{S}_{3}=216$

$\mathrm{X}_{2}+\mathrm{S}_{4}=238$

$\mathrm{X}_{3}+\mathrm{S}_{5}=142$

$\mathrm{X}_{4}+\mathrm{S}_{6}=130$

$\mathrm{X}_{5}+\mathrm{S}_{7}=112$

$\mathrm{X}_{6}+\mathrm{S}_{8}=125$

$\mathrm{X}_{7}+\mathrm{S}_{9}=155$

2. Menyusun persamaan-persamaan ke dalam tabel simpleks menjadi sebagai berikut. Iterasi 0

Tabel 3.5. Tabel Simpleks awal

\begin{tabular}{|c|c|c|c|c|c|c|c|c|c|c|c|c|c|c|c|c|c|c|}
\hline VB & $Z$ & $\mathrm{X} 1$ & $\mathrm{X} 2$ & $\mathrm{X} 3$ & $\mathrm{X} 4$ & $\mathrm{X} 5$ & $\mathrm{X} 6$ & $\mathrm{X} 7$ & $\mathrm{~S} 1$ & $\mathrm{~S} 2$ & $\mathrm{~S} 3$ & $\mathrm{~S} 4$ & $\mathrm{~S} 5$ & $\mathrm{S6}$ & $\mathrm{S} 7$ & $\mathrm{~S} 8$ & $\mathrm{~S} 9$ & Solusi \\
\hline Z & 1 & -30400 & -35462.4 & -39640 & -45800 & -48500 & -54280 & -59191.4 & 0 & 0 & 0 & 0 & 0 & 0 & 0 & 0 & 0 & 0 \\
\hline S1 & 0 & 34600 & 39537.6 & 55360 & 69200 & 86500 & 110720 & 125808.6 & 1 & 0 & 0 & 0 & 0 & 0 & 0 & 0 & 0 & 76140000 \\
\hline S2 & 0 & 1 & 1 & 1 & 1 & 1 & 1 & 2 & 0 & 1 & 0 & 0 & 0 & 0 & 0 & 0 & 0 & 1450 \\
\hline S3 & 0 & 1 & 0 & 0 & 0 & 0 & 0 & 0 & 0 & 0 & 1 & 0 & 0 & 0 & 0 & 0 & 0 & 216 \\
\hline S4 & 0 & 0 & 1 & 0 & 0 & 0 & 0 & 0 & 0 & 0 & 0 & 1 & 0 & 0 & 0 & 0 & 0 & 238 \\
\hline S5 & 0 & 0 & 0 & 1 & 0 & 0 & 0 & 0 & 0 & 0 & 0 & 0 & 1 & 0 & 0 & 0 & 0 & 142 \\
\hline S6 & 0 & 0 & 0 & 0 & 1 & 0 & 0 & 0 & 0 & 0 & 0 & 0 & 0 & 1 & 0 & 0 & 0 & 130 \\
\hline S7 & 0 & 0 & 0 & 0 & 0 & 1 & 0 & 0 & 0 & 0 & 0 & 0 & 0 & 0 & 1 & 0 & 0 & 112 \\
\hline S8 & 0 & 0 & 0 & 0 & 0 & 0 & 1 & 0 & 0 & 0 & 0 & 0 & 0 & 0 & 0 & 1 & 0 & 125 \\
\hline S9 & 0 & 0 & 0 & 0 & 0 & 0 & 0 & 1 & 0 & 0 & 0 & 0 & 0 & 0 & 0 & 0 & 1 & 155 \\
\hline
\end{tabular}


3. Menentukan kolom kunci dan baris kunci.

Iterasi 1

Berdasarkan perhitungan simpleks iterasi ke-1 diperoleh kolom ke-7 yang dipilih sebagai kolom kunci yaitu variabel $\mathrm{X}_{6}$ karena memiliki nilai negatif terbesar pada baris fungsi tujuan dan baris ke-9 dipilih sebagai baris kunci karena memiliki rasio positif terkecil yaitu 155 .

4. Mengubah nilai pada baris dan nilai-nilai diluar baris kunci.

Untuk mengubah nilai pada baris kunci yaitu dengan membagi semua koefisien pada baris kunci dengan angka kunci. Selanjutnya mengubah nilai-nilai diluar baris kunci dengan cara nilai baris baru $=$ baris lama - (koefisien pada kolom kunci $\mathrm{x}$ nilai baris kunci).

Dalam hal ini, iterasi 1 belum diperoleh solusi optimal karena pada baris fungsi tujuan masih memuat nilai negatif. Maka perhitungan dilanjutkan pada iterasi selanjutnya sampai tercapai solusi optimal. Berdasarkan perhitungan simpleks iterasi ke-1 diperoleh variabel keputusan $\mathrm{X}_{7}$ sebesar 155 .

Iterasi 2

Berdasarkan perhitungan simpleks iterasi ke-2 diperoleh variabel keputusan $\mathrm{X}_{6}$ sebesar 125 .

Iterasi 3

Berdasarkan perhitungan simpleks iterasi ke-3 diperoleh variabel keputusan $\mathrm{X}_{5}$ sebesar 112 .

Iterasi 4

Berdasarkan perhitungan simpleks iterasi ke-4 diperoleh variabel keputusan $\mathrm{X}_{4}$ sebesar 130.

Iterasi 5

Berdasarkan perhitungan simpleks iterasi ke-5 diperoleh variabel keputusan $\mathrm{X}_{3}$ sebesar 142 .

Iterasi 6

Berdasarkan perhitungan simpleks iterasi ke-6 diperoleh variabel keputusan $\mathrm{X}_{2}$ sebesar 238.

Iterasi 7

Berdasarkan perhitungan simpleks iterasi ke-7 diperoleh variabel keputusan $\mathrm{X}_{1}$ sebesar 197,82.

Iterasi 8

Tabel 3.6. Tabel simpleks iterasi 8

\begin{tabular}{|c|c|c|c|c|c|c|c|c|c|c|c|c|c|c|c|c|c|}
\hline $\mathrm{VB} Z$ & $\mathrm{X} 1$ & $\mathrm{X} 2$ & $\mathrm{X} 3$ & $\mathrm{X} 4$ & X5 & X6 & $\mathrm{X} 7$ & S1 & $\mathrm{S} 2$ & S3 & S4 & S5 & S6 & S7 & S8 & $\mathrm{S}$ & Solusi \\
\hline \begin{tabular}{l|l}
$\mathrm{Z}$ & 1
\end{tabular} & 0 & 0 & 0 & 0 & 0 & 0 & 0 & 0.47 & 0 & 14121.13 & 16860.45 & 13593.8 & 13242.25 & 7802.81 & 2187.60 & 0 & 47685060.58 \\
\hline \begin{tabular}{|l|l|}
$\mathrm{X} 1$ & 0
\end{tabular} & 1 & 0 & 0 & 0 & 0 & 0 & 0 & 0 & 0 & 1 & 0 & 0 & 0 & 0 & 0 & 0 & 216 \\
\hline \begin{tabular}{|l|l|} 
S2 & 0
\end{tabular} & 0 & 0 & 0 & 0 & 0 & 0 & 0 & 0 & 1 & -0.45 & -0.37 & -0.12 & 0.10 & 0.38 & 0.76 & 0 & 187 \\
\hline \begin{tabular}{l|l} 
S9 & 0
\end{tabular} & 0 & 0 & 0 & 0 & 0 & 0 & 0 & 0 & 0 & 0.28 & 0.31 & 0.44 & 0.55 & 0.69 & 0.88 & 1 & 5 \\
\hline \begin{tabular}{|l|l}
$\mathrm{X} 2$ & 0
\end{tabular} & 0 & 1 & 0 & 0 & 0 & 0 & 0 & 0 & 0 & 0 & 1 & 0 & 0 & 0 & 0 & 0 & 238 \\
\hline \begin{tabular}{l|l}
$\mathrm{X} 3$ & 0 \\
\end{tabular} & 0 & 0 & 1 & 0 & 0 & 0 & 0 & 0 & 0 & 0 & 0 & 1 & 0 & 0 & 0 & 0 & 142 \\
\hline $\begin{array}{lll}\mathrm{X} 4 & 0\end{array}$ & 0 & 0 & 0 & 1 & 0 & 0 & 0 & 0 & 0 & 0 & 0 & 0 & 1 & 0 & 0 & 0 & 130 \\
\hline \begin{tabular}{l|l}
$\mathrm{X} 5$ & 0
\end{tabular} & 0 & 0 & 0 & 0 & 1 & 0 & 0 & 0 & 0 & 0 & 0 & 0 & 0 & 1 & 0 & 0 & 112 \\
\hline \begin{tabular}{|l|l}
$\mathrm{X} 6$ & 0
\end{tabular} & 0 & 0 & 0 & 0 & 0 & 1 & 0 & 0 & 0 & 0 & 0 & 0 & 0 & 0 & 1 & 0 & 125 \\
\hline \begin{tabular}{l|l} 
X7 & 0
\end{tabular} & 0 & 0 & 0 & 0 & 0 & 0 & 1 & 0 & 0 & -0.28 & -0.31 & -0.44 & -0.55 & -0.69 & -0.88 & 0 & 150 \\
\hline
\end{tabular}


Berdasarkan perhitungan simpleks iterasi ke-8 pada Tabel 3.6 terlihat bahwa semua nilai pada baris fungsi tujuan bernilai positif yang artinya menunjukan solusi yang diperoleh sudah optimal. Nilai masing-masing variabel keputusan yang diperoleh yaitu $X_{1}=216, X_{2}=238, X_{3}$ $=142, X_{4}=130, X_{5}=112, X_{6}=125, X_{7}=150$ dengan $Z=47685060,58$.

\section{Kesimpulan}

Penerapan model de novo programming pada PT.X untuk masalah optimasi produksi buis beton dalam mengoptimalkan sumber daya yang tersedia agar tidak terdapat sisa digunakan metode simpleks. Hasil perhitungan diperoleh jumlah masing-masing produk buis beton yaitu buis beton tipe 20 sebanyak 216 , buis beton tipe 30 sebanyak 238, buis beton tipe 40 sebanyak 142 , buis beton tipe 50 sebanyak 130, buis beton tipe 60 sebanyak 112, buis beton tipe 80 sebanyak 125 dan buis beton tipe 100 sebanyak 150 dengan total keuntungan produksi bulan Maret 2021 yaitu Rp. 47.685.060,58. Penggunaan model de novo programming dapat mengoptimalkan bahan baku yang tersedia sehingga diharapkan mampu memenuhi spesifikasi produk buis beton yang telah ditetapkan dan keuntungan yang diperoleh maksimum.

\section{Daftar Pustaka}

[1] D. Tuwu, "Kebijakan Pemerintah Dalam Penanganan Pandemi COVID-19," Journal Publicuho, vol. 3, no. 2, pp. 267-278, 2020.

[2] Media Informasi dan Komunikasi Direktorat Jenderal Bina Konstruksi Kementrian PUPR, "Kebijakan dan Perubahan di Sektor Jasa Konstruksi di Masa Pandemi," Buletin Konstruksi Edisi 4, Jakarta Selatan, 2020.

[3] S. Assauri, Manajemen Produksi dan Operasi Edisi Keempat, Jakarta: BPFE-UI, 1993.

[4] A. Perkasa, "Optimasi Perencanaan Produksi Menggunakan Metode Linier Programming dan De Novo Programming (Studi Kasus di DD Jaya Magelang)," Universitas Islam Negeri Sunan Kalijaga, Yogyakarta, 2018.

[5] I. Gitosudarmo, Sistem Perencanaan dan Pengendalian Produksi, Yogyakarta: BPFEYogyakarta, 1982.

[6] N. Dendy dan Y. N. Kurniadi, “Analisis Model Fisik Revetment Buis Beton,” Jurnal Online Institut Teknologi Nasional, vol. 5, no. 1, pp. 106-117, 2019.

[7] I. "Efektivitas Perencanaan Produksi Dengan Pendekatan De Novo Programming," UPN "Veteran" Jawa Timur, Surabaya, 2012.

[8] E. Ariyani, "Perencanaan Produksi Dengan Metode De Novo Programming Untuk Memperoleh Keuntungan Yang Maksimal Di PT. Keramik Diamond Industries Gresik," Jurnal Penelitian Ilmu Teknik, vol. 9, no. 2, pp. 130-142, 2009.

[9] A. Kholik, E. E. Wahyudi, K. Devianto, N. Sholihah, Y. M. Santosa dan W. , "Sistem Rekomendasi Berbasis Genetic Algorithm: Studi Kasus Pembelian Komponen Komputer dan Aksesorisnya," Seminar Nasional Aplikasi Teknologi Informasi (SNATi), pp. 30-34, 2018.

[10] S. P, A. M dan H. H. T, Dasar-dasar Operations Research Edisi 1, Yogyakarta: BPFEYogyakarta, 1984.

[11] H. E, Manajemen Operasi Edisi Ketiga, Jakarta: Grasindo, 2008.

[12] I. L. Nur'aini, E. Harahap dan dkk, "Pembelajaran Matematika Geometri Secara Realistis dengan GeoGebra," Jurnal Matematika, vol. 16, no. 2, pp. 1-6, 2017.

[13] A. B. S. Merlyana, "Sistem Informasi Untuk Optimalisasi Produksi dan Maksimasi Keuntungan Menggunakan Metode Linier Programming," Jurnal Piranti Warta, vol. 11, no. 3, pp. 370-387, 2008.

[14] T. T. Dimyati dan A. Dimyati, Operations Research Model-model Pengambilan Keputusan, Bandung: Sinar Baru Algensindo, 2020. 
[15] Abdillah, Program Linear, Ambon: Dua Satu Press, 2013.

[16] M. Tabucanon, Multiple Criteria Making In Industry, New York: Elsevier Sciene, Publishing Company Inc, 1988.

[17] P. Siagian, Penelitian Operasional. Edisi Pertama, Universitas Indonesia: Fakultas Ekonomi, 1989.

[18] E. Harahap, Buku Ajar : Pemrograman Linier, Bandung: Program Studi Matematika FMIPA Universitas Islam Bandung.

[19] R. S. Budianti, A. A. Nurrahman, A. Hadian, D. Ahmadi dan E. Harahap, "Penggunaan Metode Simpleks Untuk Memaksimalkan Target Sales Pada Penjualan Paket Internet," Jurnal Riset dan Aplikasi Matematika, vol. 04, no. 02, pp. 108-114, 2020.

[20] B. Yuwono, Bahan Kuliah Riset Operasional, vol. 2, Yogyakarta: Teknik Informatika UPN, 2007, pp. 59-65.

[21] Y. Puspaningrum, "Analisis Kapasitas Produksi dan Berbagai Faktor yang Mempengaruhi Hasil Produksi Industri Sedang dan Besar di Eks Karesidenan Surakarta," Universitas Muhammadiyah Surakarta, Surakarta, 2020. 